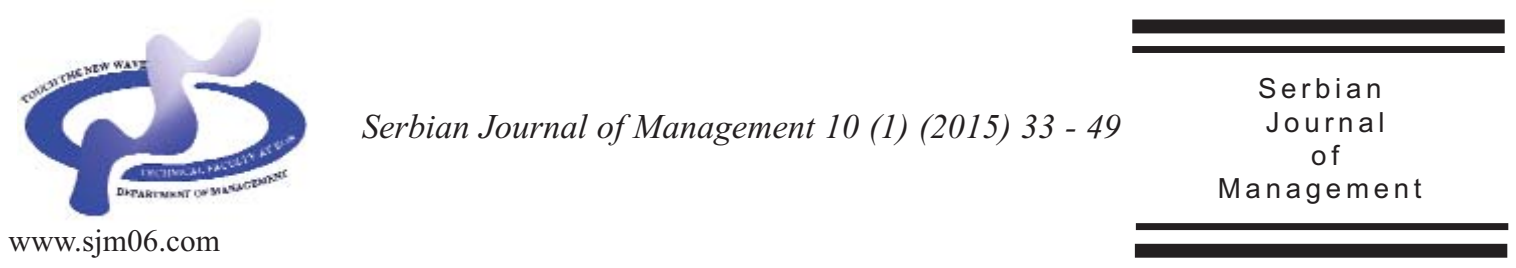

\title{
TRANSPORT OUTSOURCING AND TRANSPORT COLLABORATION RELATIONSHIP - THE RISK HEDGING PERSPECTIVE
}

\author{
Đurđica M. Stojanovića ${ }^{a *}$ and Bjørnar Ø. Aas ${ }^{b}$ \\ $a_{\text {University of Novi Sad, Faculty of Technical Sciences, Department for Traffic and }}$ \\ Transportation, Trg D. Obradovića 6, 21000 Novi Sad, Serbia

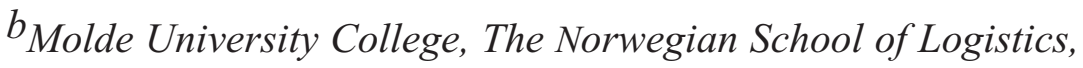 \\ PO Box 2110, NO-6402, Molde, Norway
}

(Received 9 May 2014; accepted 14 January 2015)

\begin{abstract}
Although transport outsourcing decision-making and collaborative transport management (CTM) have been "hot topics" for years, their links are still not thoroughly explored. The purpose of this paper is to contribute to a better understanding of the relationship between them. In particular, we focus on the conflicting and complementary features of these concepts with regard to their capability to hedge against transport outsourcing-related risks.

Transport outsourcing is often a tool for transferring part of the demand risks from the primary parties in supply chains to transport service providers. However, new relationships introduce some new risks - outsourcing contract risks. It is important to identify, estimate and compare such kinds of risks. Transport collaboration may decrease both the demand risks and the outsourcing contract risks, although the relationship with the latter is more complex. It is used an exploratory research based on a combination of a literature review and empirical examples.
\end{abstract}

Keywords: transport outsourcing, transport collaboration, demand risk and uncertainty, small and medium enterprises

\section{INTRODUCTION}

In many ways, the development of collaborative transportation management (CTM) in supply chains seems to be a trend opposed to transport outsourcing. The latter has usually started as an arrangement whereby a carrier performs services for a firm that were originally performed in-house (i.e. vertical disintegration), see e.g.

\footnotetext{
* Corresponding author: djurdja@uns.ac.rs
}

DOI: $10.5937 /$ sjm10-6676 
(Harland et al., 2005). The main idea is to focus on core business and let specialists, who are assumed to be more capable, to take care of non-core activities. On the contrary, CTM is treated as a tool for strengthening links between carriers or logistics providers and their customers to cross over the boundaries, i.e. to make new, "extended enterprises" (Jagdev \& Thobern, 2001). However, both concepts are of strategic importance for al involved enterprises. Furthermore, these concepts also represent the most important supply chain trends in transportation which have taken place in recent years.

The purpose of this paper is to contribute to exploring the role of transport outsourcing and CTM in hedging transport risks through providing a better understanding of their relationship. These risks both support and discourage an outsourcing decision and are trends that are likely to continue in the future. Thus, due to the strategic importance of transport outsourcing and CTM as well as their relationship which will be explored in this paper, it is important not only to analyse them separately, but also to explore the links between them. Although there is a substantial body of literature about logistics collaboration and logistics outsourcing, including transport outsourcing, there seems to be few papers which address their relationship (Cakić et al., 2007). A literature body about their relationship from the risk perspective is particularly scarce. The starting point - hypothesis in this paper is that related links have to exist. If so, due to significance of both trends in transport logistics, they may be and have to be revealed and explored more in-depth.

The paper is organized as follows. In next section, the most important risks related to transport outsourcing decision-making in
SMEs are explored and discussed. Further, a conceptual model is proposed, which depicts the relations between two kinds of transport outsourcing risks according to the adopted risk classification. The main principles of logistics and transport collaboration are described in the Section 3 and the impact of transport collaboration on transport outsourcing-related risks is briefly discussed. In Section 4, the applied case study methodology is described and in Section 5, two cases are used to illustrate the ideas presented in the previous sections. Further, the role of CTM and transport outsourcing concepts and their interrelationship in hedging transport risks is elaborated on in Section 6. Finally, implications and conclusions are presented in the last section.

\section{RISKS IN TRANSPORT OUTSOURCING DECISION-MAKING}

\subsection{Transport outsourcing}

Very few logistic trends have so far caught the attention of academics and practitioners to the same extent as outsourcing. The experts in the most developed countries have started to herald the emerging outsourcing trends (vertical disintegration) since mid-1970s (Harland et al., 2005). As a non-core activity in most enterprises, transport, together with other logistics activities has been among the first candidates for outsourcing. After the transfer or sale of resources, enterprises buy back the transport and/or related services. The level of outsourced logistics varies from simple capacities and assets outsourcing, to single processes and activities outsourcing, such as transport or warehousing, to bundled activities, where an intermediate coordinates 
integrated value-added logistics in the supply chain (Stefansson, 2006). Agreements with carriers and logistics providers vary from spot contracts to long-term agreements and strategic alliances.

However, practical experience has shown that it is very important to keep in-house expertise and control of outsourced activities; at least enough to be able to make appropriate contracts with logistics providers and properly monitor the execution of the activities (see e.g., (Wilding \& Juriado, 2004), and (Aas et al., 2008)). Wilding and Juriado (2004) support the idea that outsourcing in logistics should not be treated as an "all or nothing" kind of decision and that mixed solutions may often give the best results. In praxis, enterprises usually outsource their fleet, facilities and activities which tend to be rather transactional, operational, and repetitive, but still keep the paramount control over the activities and most of the strategic decisions in-house (Langley, 2014).

\subsection{Transport sourcing uncertainties and risks within supply chain}

Supply chain uncertainty refers to decision-making situations in the supply chain, where a decision maker has a lack of information about supply chain behaviour or its environment, lacks effective control actions and/or is unable to predict the impact of possible control actions (van der Vorst \& Beulens, 2002). In modern supply chains, the uncertainty and related risks are among the crucial issues. Risk is increasing, and is shifting around in modern complex and dynamic supply chains and networks (Harland et al., 2003). Although transport uncertainty belongs to the "supply chain uncertainty family", their relationship has so far been rarely explored in the literature. Among the exceptions is the work of Sanchez-Rodrigues et al. (2008), and their findings have partly constituted the starting point for our research, focusing on transport uncertainties from the transport sourcing perspective.

The main reasons for outsourcing relates to cost and strategy issues, such as economies of scale, core competence and flexibility. Logistics and transport outsourcing in the supply chain increase the outsourcing company's flexibility to deal with different types of changes in the supply chain. It allows sharing or passing on different risks to the carriers or logistics providers. Consequently, its importance grows in an uncertain environment. However, outsourcing normally increases the complexity and, therefore introduces other kinds of uncertainties and related risks in supply networks (Harland et al., 2003). Logistics outsourcing also usually leads to an increased supply chain complexity, whereby the outsourced processes become harder to control and manage. Berger et al. notice that although outsourcing can be one of the most risky decisions for a firm, its related risk, as well as the potential to mitigate such risk are scarcely considered in the literature (Berger et al., 2005).

In this paper, all uncertainties and related risks have been classified from the transport outsourcing perspective into two categories "external" and "internal", according to Cakić (2009) and Stojanović et al. (2013). External outsourcing risks that are important for transport managers, are concerned with supply chain demands, and consequently, transport orders. Indirectly, they also include the impact of factors like industry, business strategy, market, and the economic environment. All of them are concerned here 
as transport demand uncertainties and related risks. On the other hand, all risks related with the transport service provider-customer relationship are called internal outsourcing risks. They involve risks related to any of the transport sourcing decisions in the interorganizational decision-making process, such as insourcing, purchasing, outsourcing, backsourcing, as well as the nature of contracts with service providers, the number of involved carriers and the changing of service provider. In the outsourcing literature, internal and external outsourcing risks are usually identified as motivators and obstacles for an outsourcing decision. The list of particular risks given in Table 1 should not be considered to be complete.

Although in some listed papers outsourcing risks in supply chains are considered in rather a general manner, we regard the findings as applicable to transport and logistics outsourcing as well. Some authors also notice that the literature body about logistics risks in supply chain is scarce, compared with the one about other supply chain risks (Maslarić et al., 2012). If we focus on given transport outsourcing risks, the gap is even more obvious. Further, looking at the risks in Table 1, one may notice that global companies and SMEs may have different criteria in logistics outsourcing decision-making, or rank the factors influencing an outsourcing decision differently (Finch, 2004).

Following such classification of risks, it can be seen that their relationships with the transport outsourcing decision are different in essence, from the viewpoint of outsourcing enterprise. This difference is depicted by the conceptual model given in Figure 1 (Cakić, 2009). The demand variability and amplification related risks can negatively affect the transport performance (Potter \& Lalwani, 2008). Transport outsourcing can push these external risks towards the service provider. On the other hand, internal outsourcing risks increase with the level of transport outsourcing, i.e. outsourcing of capacities vs. outsourcing of management functions. Furthermore, internal risks could rapidly rise with the complexity of the outsourced activities, i.e.

Table 1. List of external and internal transport outsourcing risks, which are recognized in the literature

\begin{tabular}{|c|c|}
\hline $\begin{array}{c}\text { External transport outsourcing risks } \\
\text { (motivators to outsourcing) }\end{array}$ & Internal transport outsourcing risks (obstacles for outsourcing) \\
\hline $\begin{array}{l}\text { Lack of flexibility to change and configure } \\
\text { the resources to meet changing market } \\
\text { needs (Harland et al., 2003) } \\
\text { Lack of flexibility for changing business } \\
\text { conditions and fluctuating demands for } \\
\text { products, services and rapidly developing } \\
\text { technologies (Greaver, 1999) } \\
\text { Demand variability and amplification of } \\
\text { related risks (Potter \& Lalwani, 2008) } \\
\text { Risk factors in international outsourcing: } \\
\text { currency exchange rate variability, use of } \\
\text { non-tariff barriers (NTBs), government } \\
\text { stability, social stability, social/cultural } \\
\text { differences, legal system stability, } \\
\text { legal/cultural differences (Schniederjans \& } \\
\text { Zuckweiler, 2004) }\end{array}$ & $\begin{array}{l}\text { Risks related to increasing complexity in supply chains and networks - } \\
\text { strategic risk, operations risks, supply risk, customer risk, asset impairment } \\
\text { risk, reputation risk (Harland et al., 2003) } \\
\text { Failure to identify core and non-core activities may lead to outsourcing of } \\
\text { core activities. Lack of skills and competence to manage outsourcing } \\
\text { relationships. Increased costs in relationship management. Lack of } \\
\text { understanding, skills and competence to design appropriate service level } \\
\text { agreements with outsource company (Harland et al., 2005) } \\
\text { Lack of possibility to change an outsourcing decision, back insource, or } \\
\text { change logistics provider (Kakabadse \& Kakabadse, 2000) } \\
\text { Provider selection risks, management risks and implementation risks } \\
\text { (Anonimous, 2004) } \\
\text { Lost service quality (Rao \& Young, 1994) } \\
\text { The risk of inefficient management, latent information asymmetry, loss of } \\
\text { logistics innovative capacity, hidden costs, dependence on the third party } \\
\text { logistics provider, loss of control over the third party logistics provider, } \\
\text { problems of evaluating and monitoring third party logistics provider } \\
\text { performance, conflicts between firms' cultures (Wang \& Regan, 2003) }\end{array}$ \\
\hline
\end{tabular}


with the bundling of transport with other logistics activities and with outsourcing of processes. Thus, the rough risk estimation in the model indicates that it does not only matter whether a particular operation or management task is outsourced, but also its links with other transport or logistics activities. In order to avoid external outsourcing risks, a firm will tend to enforce service provider responsibility and share the goals in the supply chain with a few numbers of specialists. Main measures in hedging internal risks include increasing the control, keeping management in house, establishing a monopolistic position and using spot contracts when contracting carriers.

In its efforts to minimize both the external and internal transport outsourcing risks, a firm has to permanently evaluate the transport sourcing decision and develop the related management tools and mechanisms. Such mechanisms should include risk identification and evaluation. The model is based on the belief that a firm's outsourcing decision should be in the equilibrium of both risks. As mentioned above, this will be situation dependent since the equilibrium will be moved if actions are taken to reduce the external and/or internal risks. It is also supposed that the risk functions are asymptotic rather than linear, as they are influenced by many factors.

Presented conceptual model belongs to the group of very rare normative models in the transport outsourcing literature which describe transport outsourcing risks. It also seems to be very suitable as a basis to continue the research on relationship between transport outsourcing and transport collaboration from the risk perspective.

\section{IMPACT OF CTM ON TRANSPORT OUTSOURCING RISKS}

In Section 1, it was pointed out that collaboration in logistics and particularly transport, are among the most important

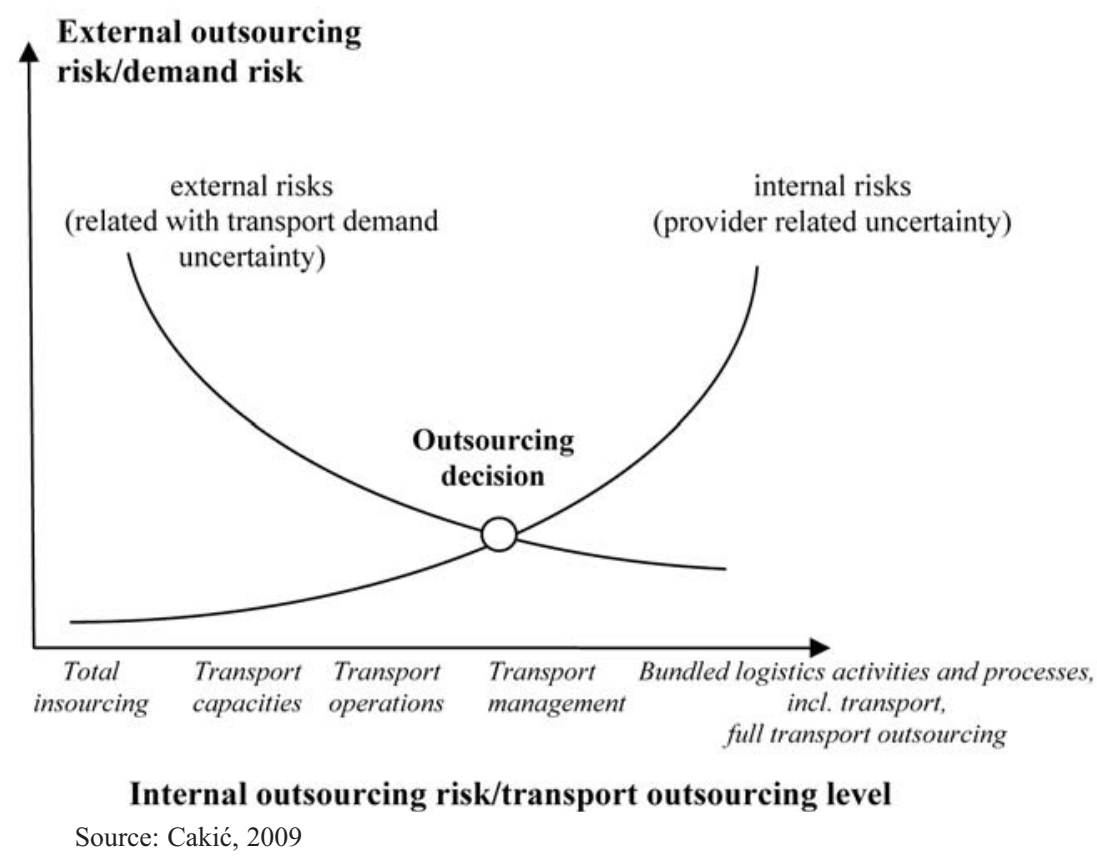

Figure 1. The relationship between external and internal transport outsourcing risks 
trends in logistics. Collaboration has been described as an attempt to fully satisfy the concerns of the parties involved in exchange, in order to achieve an integrative settlement (see e.g. (Esper \& Williams, 2003)). The rising interest in this idea has been recorded since the beginning of the new century. In the logistics area, the focus of academics is on collaborative relationships between the main players in supply chains on the one hand, and carriers and logistics operators and their customers, on the other hand. The first one is related to Collaborative Planning, Forecasting and Replenishment (CPFR) and associated processes. The latter direction is known as Collaborative Transport Management (CTM). The idea is that all involved companies should share benefits and risks, working together towards common objectives to reach win-win(-win) solutions. The objective of CTM is "to improve the operating performance of all parties involved in the relationship by eliminating inefficiencies in the transportation component of the supply chain through collaboration" (VICS, 2008).

According to (Tyan et al., 2003), CTM is a "new business model for integrating transportation management with supply chain management". Esper and Williams (2003) are more precise and say that "CTM essentially involves converting order forecasts developed via CPFR, into shipment forecasts, and collaboratively ensuring their accurate fulfillment".

Both the collaboration concepts are today enabled and closely supported by modern information systems and Internet-based technologies (Esper \& Williams, 2003). However, the information systems and information technology development, as well as information and functional integration, have usually not been accepted and developed at an equal rate amongst all partners within logistics dyads and triads (Patterson et al., 2004). Generally, SMEs are rarely drivers of collaborative relationships because it can be expensive, risky and often without clear and fast benefits for such enterprises. However, depending on the industry, supply chain strategy and/or impact of other (often more powerful) partners, SMEs should sooner or latter consider information integration and other aspects of collaboration with other supply chain members.

The papers concerned with CTM argue that substantial benefits can be obtained by CTM (see e.g. (Esper \& Williams, 2003; Tyan et al., 2003)). The main view is that CTM can reduce costs, increase visibility, flexibility and process control. It can also improve overall transport performance, add value to supply chains and create benefits for all parties. CTM introduces a carrier or a logistics provider as a strategic partner and a value-adding contributor to supply chain processes. However, similar to the early stages of other emerging trends in logistics, much more evidence is provided about potential advantages than the risks related with collaboration and integration. Also, the review of the body of CTM literature shows that most papers are focused on operational aspects and collaboration effects, than on higher transport management levels and the relationship between CTM and other strategic decisions, including transport sourcing.

According to the body of literature; it can be concluded that the phrase "risks shared between the parties" within CTM is related to hedging against both transport demand risks and carrier/logistics provider-related risks. As an extension of CPFR, CTM should decrease transport demand uncertainty for 
the carrier and, consequently, the risk. Further, CTM obtains increased visibility and better control of transport processes, so the risk of carrier opportunism should also be reduced. Even in case of implemented CPFR and related concepts without developed CTM, still there is room for using the benefits of information integration in hedging transport demand risks e.g. if transport managers are distributors, not carriers. However, information integration within a logistics triad may induce some new business risks, such as bad investment into a long-term relationship with the service provider, including unnecessary IT investments and the need for trust (VICS, 2004). There are also risks related with information inaccuracy and inadequate ICT management within the logistics triad. According to (Sanchez-Rodrigues et al., 2008), such issues are related to the control of systems uncertainties. Thus, while CTM development has clearly an inverse relationship with external transport outsourcing risks, its relationship with internal transport outsourcing risks seems to be more complex, reversible and more situation dependent. However, according to Figure 1, if logistics and, particularly, transport collaboration impact on both risks, it should also impact on an outsourcing decision.

\section{METHODOLOGY}

To support and illustrate the ideas proposed in previous sections by the use of practical examples, the successful SMEs in Serbian market have been investigated. In order to be selected as cases for our research, SMEs had to meet two main conditions - to have some kind of logistics collaboration in the supply chain and to perform some level of transport outsourcing. An additional condition which focal enterprises had to meet was to exemplify good praxis.

After considering business data and talking to several practitioners, two examples were selected. These are regarded to be suitable for research and are presented in the next section in detail. Semi-structured interviews with top managers, as well as with representatives for the relevant IT, distribution or marketing departments within the enterprises have been carried out. A common set of questions was prepared to collect relevant information regarding the firms' size, position in supply chain, supply chain strategy, changes related to the process of privatization, distribution system features, main management information system (MIS) and collaborative application features. This approach obtained a suitable basis for crosscase study analysis and further generalization of results.

\section{EMPIRICAL EXAMPLES}

\subsection{Example A}

The first firm is a successful Serbian manufacturer of carpets and other floor covering products. The enterprise was a part of a larger group - corporation (now Serbian part of company, in further text: corporation), and now it is also a part of the global company, with the core business being the production, sales and distribution of floor covering. The corporation in Serbia included several manufacturers of all types of floor covering products (i.e. mainly carpets and laminates), a wholesaler/distributor and a retail enterprise, which focused mostly on the Serbian and the southern and eastern 
European markets. In 2000, the corporation outsourced its transport fleet and created a number of small carriers in the local market, with revolving middle-term agreements according to a social programme. Furthermore, the manufacturer outsourced its transport and inventory management in distribution to the wholesaler/distributor, which was also a part of the corporation. In 2003, the corporation started to implement the Enterprise Resource System SAP II, recently upgraded into SAP III, and so enabling integrated ordering, integrated inventory and warehouse management across the whole distribution chain. Due to the kind of industry and level of inventory information sharing, the demand throughout the supply chain was mostly predictable, so the external transport outsourcing uncertainty was estimated as low (Table 2).

The available contract carriers' fleet has been slightly oversized for current demands and thus the outsourcing enterprise enjoyed a competitive transport environment (a situation rendered possible by local circumstances). The group used this transport outsourcing solution primarily, although not exclusively, to minimize transport costs. With this outsourcing solution, the group minimized internal outsourcing risks, and transferred the external transport outsourcing risks towards the carriers, even though these risks are low.

Although corporation had an excellent technological basis for CTM development, the operative transport planning and scheduling for the whole distribution system were performed manually, based on the skills and the experience of the dispatchers. The outsourcing contracts exemplify a highly asymmetric relationship and small carriers couldn't do much about transport management decision-making at any level or within any management function. Though, the corporation was not interested to introduce CTM - its hard monopolistic position and strong process control made it possible to obtain most of the benefits without any investment in CTM. Therefore, the condition for real collaboration between the involved parties was not present.

\subsection{Example B}

The second enterprise has been the one of the most successful and fastest growing IT companies in Serbia in the last decade. This enterprise was also representative to illustrate the influence of supply chain characteristics on both transport outsourcing arrangements and CTM praxis. The stakeholding IT group consisted of several SMEs, where the distributors for the Serbian and some neighbouring markets and a retailer are involved in the supply network. The enterprise has developed its own distribution network, but it also had agreements with some other distributors and retailers. The group has been among the first which has managed to realize successful B2B solutions within this industry in Serbia. Since 2008, almost all order transactions (more than $75 \%$ ) have been executed electronically. Additionally, they have developed a B2C portal for e-shopping and so created direct contact with end-users. In this industry, the demand uncertainty is high (Lee, 2002) and information sharing and collaborative inventory planning play a valuable role in order to decrease the degree of uncertainty.

The distributor used different transport sourcing concepts for the B2B and B2C solutions. In the first case, it used an ownaccounted fleet, which consisted of new vehicles, customized for the purpose of B2B flows. In the second case, they have 
developed an e-fulfilment system, where an express delivery company was involved and made deliveries to the end-users. After creating an order in the $\mathrm{B} 2 \mathrm{C}$ system, a related transport order was automatically generated and forwarded to the express company who make the delivery within 24 hours. All transport operations and management were forwarded to the transport specialist and the distributor only controls delivery complaints and claims. It has also continually reduced its own-account fleet and increased the number of express deliveries to other outbound B2B flows, i.e. towards flows from a central warehouse to other wholesalers. Own-account transport has been kept for a while for the flows from the warehouse to their own retail network.

Transport service was used to improve the total service quality and add value to the final product, particularly in $\mathrm{B} 2 \mathrm{C}$ solution. Demand risks, i.e. external outsourcing risks (compared to Example A) were partly reduced by information integration between the main parties (for example, related to stocks out) and additionally by sharing information between the distributor and transport specialist (for example, related to on-time delivery). The internal outsourcing risks were estimated from low/moderate to moderate/high, depending on the adopted transport sourcing concept (Table 2). In case of B2B commerce, a high level of demand uncertainty may lead to a lower utilization of the own-accounted fleet. In the B2C case, the internal risk is estimated as moderate/high for a couple of reasons. First, although a revolving middle-term agreement with the specialist exists, there are several companies in the Serbian market which were capable of providing satisfactory delivery services at the moment, and so to obtain a competitive environment. Second, control over transport operations was still kept in-house since the focal enterprise has direct contact with customers and therefore gets information about claims, including transport service. Such information can be used later for longterm planning, i.e. modifying transport contracts, or even as a decision basis for changing the specialist. Indeed, the selected level of outsourcing in the last case,

Table 2. The comparative overview of outsourcing risk related firms' characteristics

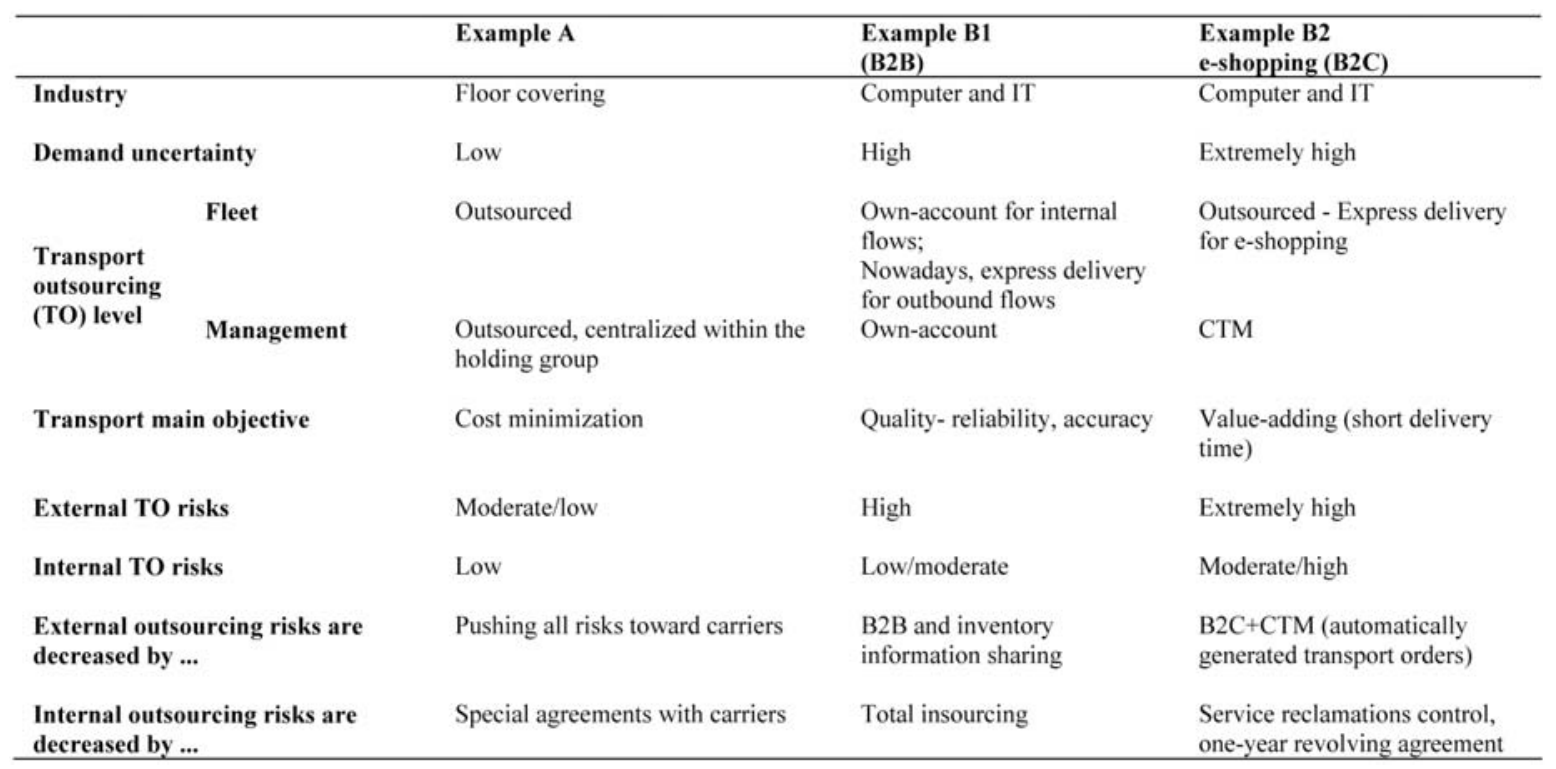


contributes much more to reduce the external outsourcing risks than it negatively influences the internal outsourcing risks. At the same time, the distributor was allowed to offer a high and equal level of delivery service to all customers, disregarding its own transport capacity constraints and thus was able to reach the company's business goals. This kind of service could be obtained by the public postal operator, or numerous private operators. The former provides an universal, but also other postal, express or courier services in the entire territory of the Republic of Serbia, while the latter offer services, which are partly subject to the restrictions related to the shipment weight, delivery cost etc. (Kujačić et al., 2011).

In Table 2, the main characteristics of the focal firms, their chosen transport sourcing concepts, related risks and ways for risk hedging are summarized. In Example B, different transport sourcing solutions in B2B and $\mathrm{B} 2 \mathrm{C}$ concepts are analysed separately, as $\mathrm{B} 1$ and $\mathrm{B} 2$ respectively.

\section{DISCUSSION ON THE ROLE OF CTM AND TRANSPORT OUTSOURCING CONCEPTS IN HEDGING RISKS}

In the previous section, the proposed ideas were illustrated in a real environment by using two enterprises. It is shown that logistics collaboration influences transport outsourcing decisions and vice versa. In given conditions, enterprises have minimized internal outsourcing risks in different ways, through: a) creating a monopolistic position regarding the carriers and keeping transport management in-house (Example A) and b) in-sourcing both the transport fleet and management (Example
B1). The transport service quality level in Example B2, is controlled by direct contact with customers in case of claims and it should also prevent carrier opportunism. Such control is based on traditional communication methods and so cannot be attached to the collaboration issue. On the other hand, external outsourcing risks are hedged by logistics collaboration, i.e. better communication and information integration between the main supply chain members (Example B1), as well as the parties in logistics triad (Example B2). Both outsourcing decisions and collaboration initiatives depend on the industry, supply chain strategy and other main characteristics of the firm.

CTM can decrease internal outsourcing risks through two-way visibility and control. In our last example (B2), only one-way visibility, i.e. inventory and orders visibility is obtained as input data in CTM. This allows reduced lead time and helps the transport specialist improve transport performance. However, in further CTM development, even better control and real-time visibility of carrier service could be considered in firm B. The importance of such feedback information increases with the level of the internal transport risks, i.e. the level of dependency and the power balance. Finally, in this case transport collaboration introduces low internal outsourcing risks, because the integration could be performed relatively easily, the investment was low and the technology compatibility is high. Also, several service providers are capable to provide the service quality level, and necessary IT basis in the Serbian market. Therefore, the risk of carrier's opportunism has been neglected.

Figure 2 depicts the risk estimations in our examples. The internal and external risks 


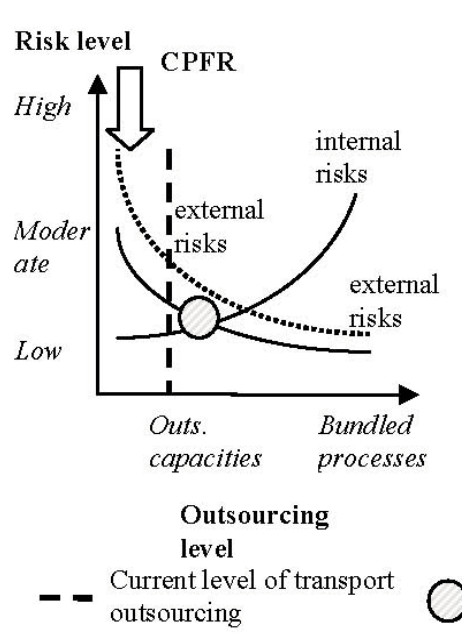

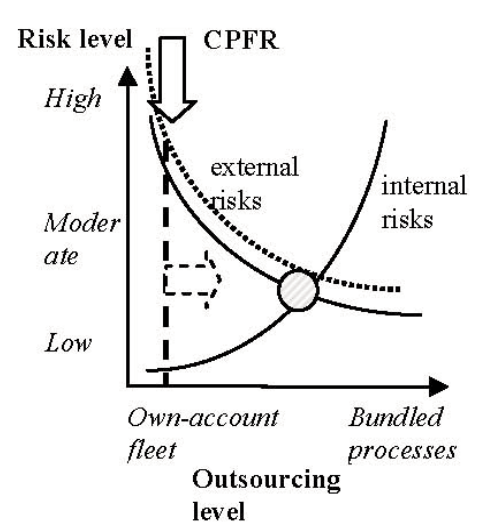

Risk

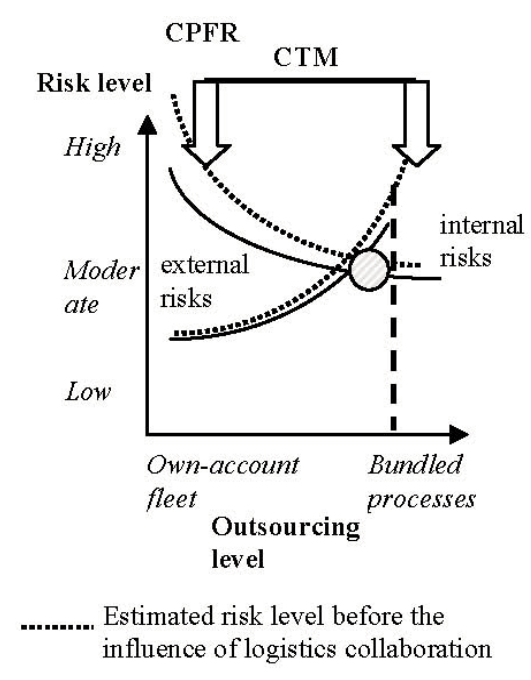

Figure 2. Risk estimation associated with current outsourcing decisions and changes related with impact of collaboration in given examples

are described according to the Figure 1 and discussion in the second Section, and estimated according to Table 2 and the characteristics of the firms described in the previous section. The level and shape of the risk functions are estimated very roughly, according to the supply chain strategy, the industry, the kind of transport contract, the requested level of transport service and the number of available service providers in the market. Figure 2 also includes the detached impact of the two identified ways of logistics collaboration (CPFR and CTM) on the particular kinds of risk.

Dashed line parallel with y-ordinate expresses the current level of transport outsourcing and estimated level of transport risks in the examples. The dashed line cuts the curves and so determines the level of particular risks. Further, the figures point out the position of current risk levels regarding the risk equilibrium in examples. It is also summarized the impact of logistics collaboration on internal and external risks decreasing in the particular examples. Dotted curves represent the risks level before the impact of CPFR and CTM. The introduction of CPFR decreased external risk and so the enterprise found its way to be closer to the risk equilibrium in given example. However, it is not fully extended into CTM, because collaboration is still in-house - between transport managers and primary parties in the supply chain. Also, there are not applications which transform orders into transport demands, as an extension of CPFR.

In the B1 example, it is estimated that the risk equilibrium is the farthest from the current sourcing solution, compared with other two examples. That may indicate that the current sourcing concept is not suitable for demand characteristics. It was partly fixed by introduction of CPFR, which may contribute to improved transport planning in the company. Further measures to reach risk equilibrium may be to change the sourcing concept (shift toward outsourcing) and to introduce CTM. Combined CPFR and CTM give the best visibility between the parties and, consequently, to overall transport risk decreasing (Example B2).

Following the theoretical framework 
provided in Sections 2 and 3, two main observations arise here. First, the identified impact of logistics collaboration should be included in the model proposed in Section 2. Second, only the B1 example shows that there is a considerable difference between the risk equilibrium and the current outsourcing decision. However, it is recorded that firm $\mathrm{B}$ in this case, tends to increase the level of outsourcing and is gradually transferring more and more responsibility to the specialist, i.e. is shifting the vertical dashed line (current state) to the right. Thus, the findings indicate that the enterprises in praxis intuitively look for an outsourcing decision that lies in the risk equilibrium as described in proposed model.

Following the first observation, we have revised the model proposed in (Cakić, 2009) (Figure 3). The logistics collaboration on the whole decreases a particular external and/or internal outsourcing risk. CPFR and related concepts (e.g. VMI) mainly impacts indirectly on transport demands, through demand characteristics and visibility in the supply chain. Introducing CTM may increase visibility and control and therefore decrease both transport demand and transport outsourcing risks. However, some CTM development risks, related to investment in collaboration and dependency, are superposited with the internal outsourcing risk. CPFR impacts on external risks directly or indirectly, through CTM. The way and intensity of its impact depend on how much CTM is developed. CTM have an impact on the risk level, i.e. positions of both risk curves in the graph separately or mutually. Consequently, CTM impacts on the position of the equilibrium of risks. Thus, it should also influence the optimal transport sourcing solution. The model can be used to explain and justify the need for the development of collaborative relationships with transport service providers, or for keeping transport service in-house. The suitable room for logistics collaboration is identified if any of the internal or external outsourcing risks are estimated to be in the higher part of the chart in Figure 3. Although the 2D model in Figure 3 does not completely depict it, decisions about CTM development should also be influenced by the outsourcing risks, as well as the risks related to CTM development, which were identified in Section 3.

The model also offers an explanation regarding some phenomenological aspects of CTM development. One of these is why the collaboration between a focal (outsourcing) enterprise and many small, non-integrated carriers (outsources) usually does not work. A second is why collaboration is more important when using third party logistics providers (3PL) than when using carriers. From a theoretical viewpoint, this is also consistent with the findings of Holcomb and Hitt (2007), who discuss the difference between strategic outsourcing, strategic purchasing and strategic alliances.

To conclude, transport outsourcing and CTM represent two different approaches to hedging transport risks. While transport outsourcing represents an effort to transfer all, or parts of the demand risk towards the carrier (passive approach), CTM represents a means to share control and responsibility with the carrier (active approach). The latter also may be based on a wish to avoid the possible negative effects that appear as a consequence of having to increase the outsourcing level. However, higher internalization of management and control in some cases could save the money needed for investments in collaboration with a service provider. Therefore, the model can be also 
used as a framework in considering CTM development within the logistics triad in the praxis.

The proposed model is consistent with all categorizations of logistics collaboration and transport and logistics outsourcing modes found in the literature. It also contributes to clarifying the links between transport outsourcing and CTM by emphasizing and providing the transport outsourcing related risk perspective. Obviously, a chosen outsourcing concept in the next stage will be an important precondition to support or inhibit the development of collaborative links in the logistics triad. Consequently, the choice of a particular transport sourcing concept and level of CTM development, which are two conceptually strongly interdependent decisions, should not be regarded separately. These two concepts are not clear opposites. They should be regarded as strong complementary concepts depending on various circumstances related to the nature of the risks and the characteristics of the firms. In addition, a decision about the collaboration with carriers is by itself an indicator for stronger and more complex relationships to carriers, and consequently is in accordance with the more extreme outsourcing levels in Figure 3.

The model also has some serious limitations. In real life, SME managers must make decisions about transport outsourcing and/or CTM development regarding other important aspects, such as business strategy, investment assessments, cost reduction assessments and service quality assessments. Therefore, the model outcome should be treated as only one among several key factors in the decision-making process. It must also be noticed that the risk estimation in the given examples are only sketched and

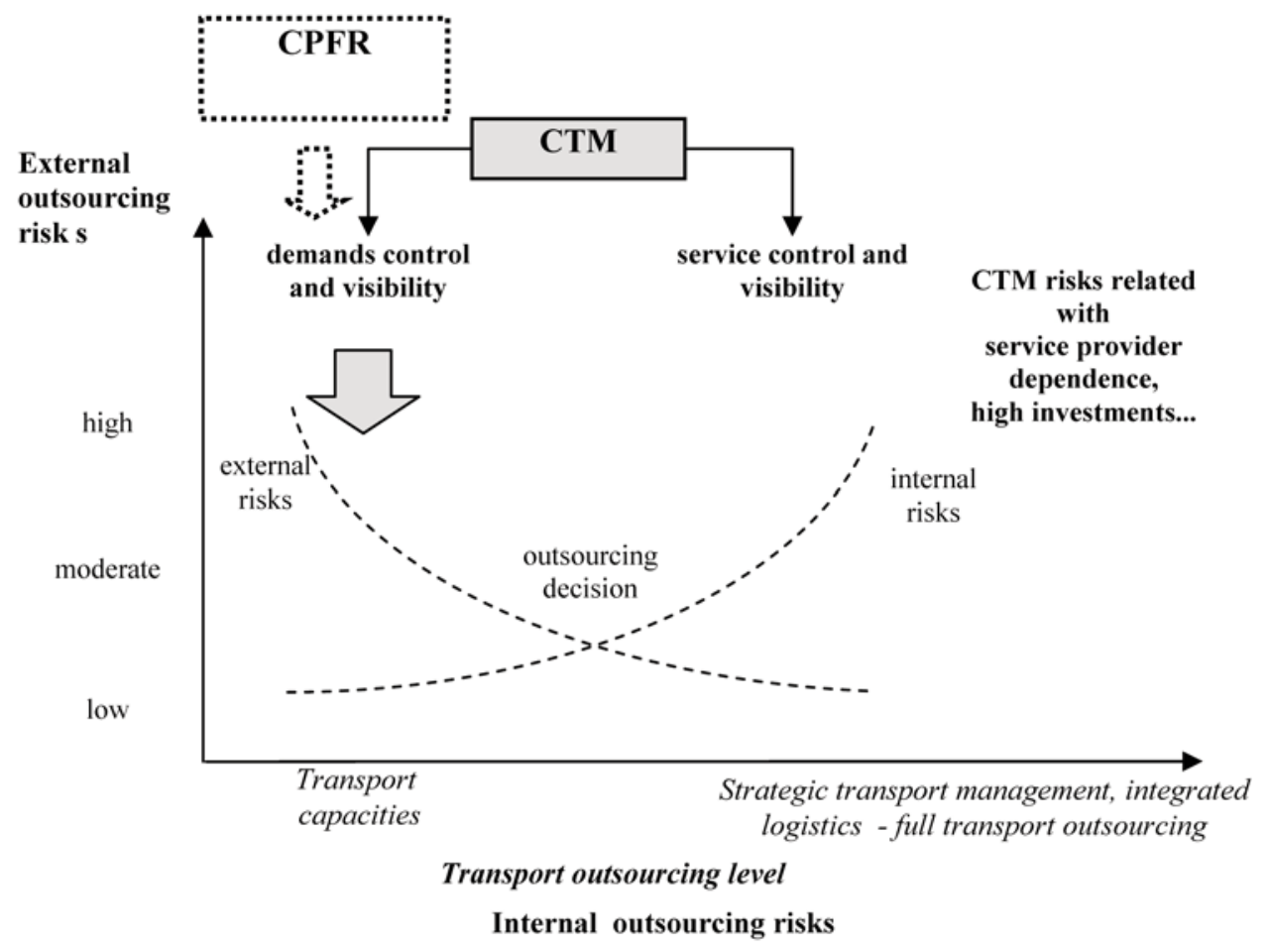

Figure 3.The relationship between transport demands risks, transport outsourcing risks and CTM risks 
in some aspects the proposed model seems rather intuitive than firmly backed and explained by the examples. Although authors feel that the model adequately describes the impact of transport collaboration on transport outsourcing risks, it is based on and explained by two case studies and therefore it is rather crude. The same comment can be made about the reverse loop between the transport outsourcing level and CTM risk. Managers can therefore use this model as a rough basis in making relationship between transport outsourcing and collaboration decisions. However, further research is necessary to develop more sophisticated normative models.

The model is in essence dyadic (e.g. describes transport service providercustomer relationships) and a more complex environment with intermediates is not fully explained. For example, in Example A, current situation probably directs a shift of the future CTM development from a "distributor-carrier" relationship towards a "transport service provider-customer" relationship, e.g. towards the main parties in the supply chain. In such a case, the proposed model should be more sophisticated and relate identified internal risks with all parties in the triad/multiad.

\section{IMPLICATIONS AND CONCLUSION}

The findings has both, theoretical and practical implications. The risks related to transport demand and supply are used as a basis for developing a conceptual framework which depicts the comparative impacts of transport outsourcing and logistics and transport collaboration on the hedging of transport demand risks. It is also argued that the transport sourcing decision and transport collaboration development create their own risks which are interrelated and create a continuous loop. In a dynamic environment, firms should continuously evaluate, correlate and coordinate them in order to hedge the risks related with both concepts. We have been unable to find presentations of this complex relationship in published academic literature.

The proposed model does not intend to give a comprehensive explanation of the impact of logistics and particularly transport collaboration on transport sourcing decisions and vice versa. Rather, the paper stresses the importance of their relationship for further research, as well as in real-life decisionmaking, focusing on a particular aspect of their relationship - the hedging of transport risk. However, in real life managers mostly make decisions regarding other important aspects, such as strategy, cost reduction and service quality. The research could also have practical implications - the findings may be helpful for SMEs to correlate their transport sourcing concept and CTM development.

Further research could be directed in different ways. For example, it could be theoretical and provide more knowledge about the interrelationship between the two trends, which have been among the most important supply chain trends (Bowersox et al., 2000). Research could be also rather practically oriented and explore the in-depth interdependence between two concepts towards normative models for hedging transport risk. Later should cover comprehensive survey and different industry sectors in Serbia and so indices the overall state in an emerging economy. Our research has focused on SMEs. However, it could be interesting to explore the studied relationships in large companies as well, because the reasons for outsourcing and 
collaboration, and consequently the risks, may differ from SMEs, particularly in an international context. Finally, we used an exploratory approach, to explain the relationship between two major trends in transport logistics. However, further research may include a range of different qualitative and quantitative methods and techniques, as well as their combination. For example, optimization models could be developed to describe the impact of CTM on transport outsourcing risks, or dynamic programming (backward propagation) could be used to model transport outsourcing.

\section{Acknowledgement}

The research in this study was partly financially supported by the Serbian Ministry of Education and Science (Project No. TR36030).

\section{References}

Aas, B., Buvik, A., \& Cakić, Đ. (2008). Outsourcing of logistics activities in a complex supply chain: a case study from the Norwegian oil and gas industry. International Journal of Procurement Management, 1 (3), 280-296.

Anonimous (2004). 40 outsourcing risks you need to know now, Logistics Today, October, 45 (10), 24.

Berger, P.D., Gerstenfeld, A., \& Zeng, A.Z. (2005). The optimal use of standby suppliers: A decision-analysis approach. International Journal of Logistics: Research and Applications, 8 (1), 67-79.

Bowersox, D.J., Closs, D.J., \& Stank, T.P. (2000). Ten mega-trends that will revolutionize supply chain logistics. Journal of Business Logistics, 21 (2), 1-16.

\title{
ОДНОС ИЗМЕБУ ТРАНСПОРТНОГ АУТСОРСИНГА И КОЛАБОРАЦИЈЕ У ТРАНСПОРТУ - АСПЕКТ ЗАШТИТЕ ОД РИЗИКА
}

\author{
Ђурђица М. Стојановић, Bjørnar Aas
}

\begin{abstract}
Извод
Иако одлучивање о транспортном аутсорсингу и колаборативном транспортном управљању представљају актуелну проблематику годинама, њихове везе нису сасвим истражене. Сврха овог рада је да допринесе бољем разумевању односа између њих, са посебним освртом на сагласне и конфликтне карактеристике ових концепата у односу на потенцијале заштите од ризика који се јављају при транспортном аутсорсингу.

Транспортни аутсорсинг се често користи да се део ризика повезаних са транспортним захтевима пренесе са примарних страна у ланцу снабдевања на носиоце транспортне услуге. Међутим, нове везе уводе неке нове ризике - ризике повезане са уговором о аутсорсингу. Важно је да се такви ризици препознају, процене и упореде. Колаборација у транспорту може да умањи и ризике транспортних захтева и ризике повезане са транспортним уговорима, иако је веза са потоњим комплекснија. Истраживање је обухватило преглед релевантне литературе и емпиријске примере.
\end{abstract}

Кључне речи: транспортни аутсорсинг, колаборација у транспорту, ризици и неизвесност захтева, мала и средња предузећа 
Cakić, Đ., Maslarić, M., \& Nikoličić, S. (2007). The relationship between collaborative management and transport sourcing in supply chains, Book of Proceedings of the 12th International Symposium on Logistics (12th ISL), 8-10 July 2007, Budapest, Hungary, 579- 584.

Cakić, Đ. (2009). Transport sourcing design in supply chain, Ph.D. thesis, Faculty of Technical Sciences, University of Novi Sad, Novi Sad, Serbia. (In Serbian).

Esper, T.L., \& Williams, L.R. (2003). The value of collaborative transportation management (CTM): Its relationship to CPFR and information technology. Transportation Journal, 42 (4), 55-65.

Finch, P. (2004). Supply chain risk management. Supply Chain Management, 9 (2), 183-196.

Greaver, M.F. (1999). Strategic Outsourcing: A Structured Approach to Outsourcing Decisions and Initiatives, American Management Association, New York.

Harland, C., Brenchley, R., \& Walker, H. (2003). Risk in supply networks. Journal of Purchasing \& Supply Management, 9, 51 -62 .

Harland, C., Knight, L., \& Lamming, R. (2005). Outsourcing: assessing the risks and benefits for organisations, sectors and nations. International Journal of Operations \& Production Management, 25 (9), 831-850.

Holcomb, T.R., \& Hitt, M.A. (2007). Toward a model of strategic outsourcing. Journal of Operations Management, 25, 464-481.

Jagdev, H.S., \& Thobern, K.D. (2001). Anatomy of enterprise collaborations. Production planning \& control, 12 (5), 437451.

Kakabadse, N., \& Kakabadse, A. (2000). Outsourcing: a paradigm shift. Journal of
Management Development, 19 (8), 670-728.

Kujačić, M., Šarac, D., Jovanović, B., \& Marković, D. (2011). Providing universal service in developing countries. African Journal of Business Management, 5 (4), 1158-1165.

Langley, C.J. (2014). The State of Logistics Outsourcing, Third-Party Logistics - Results and Findings of the 18th Annual Study, Capgemini, PennState, Penske, Corn/Ferry International and Eye for Transport, US.

Lee, H.J. (2002). Aligning Supply Chain Strategies with Product Uncertainties. California Management Review, 44 (3), 105119.

Maslarić, M., Huiskonen, J., Groznik, A., \& Bačkalić, T. (2012). Supply Chain Risk Management: Literature Review with Risk Categorization and Papers Classification, In: Kersten, W., Blecker, T., \& Ringle, C.M. (Eds.): Managing the Future Supply Chain, Current Concepts and Sollutions for Reliability and Robustness, Band 9, EUL Verlag, 101-116.

Patterson, K.A., Grimm, C.M., \& Corsi, T.M. (2004). Diffusion of Supply Chain Technologies. Transportation Journal, 43 (3), 5-23.

Potter, A., \& Lalwani, C. (2008). Investigating the impact of demand amplification on freight transport. Transportation Research Part E: Logistics and Transportation Review, 44 (5), 835-846.

Rao, K., \& Young, R.R. (1994). Global Supply Chains: Factors Influencing Outsourcing of Logistics Functions. International Journal of Physical Distribution \& Logistics Management, 24 (6), 11-19.

Sanchez-Rodrigues, V., Stantchev, D., Potter, A., Naim, M.M., \& Whiteing, A. (2008). Establishing a transport operation focused uncertainty model for the supply 
chain. International Journal of Physical Distribution \& Logistics Management, 38 (5), 388-411.

Schniederjans, M.J., \& Zuckweiler, K.M. (2004). A quantitative approach to the outsourcing-insourcing decision in an international context. Management Decision, 42 (8), 974-986.

Stefansson, G. (2006). Collaborative logistics management and the role of thirdparty service providers. International Journal of Physical Distribution \& Logistics Management, 36 (2), 76-92.

Stojanović, Đ., Gajić, V., \& Veličković, M. (2013). Relationship between supply chain strategies and transportoutsourcing goals - The risk perspective, LOGIC, 1. Logistics International Conference, Belgrade: University of Belgrade, Faculty of transport and traffic engineering, 28-30 November, 274-278.

Tyan, J.C., Wang, F.K., \& Du, T. (2003). Applying collaborative transportation management models in global 3PL. International Journal of Computer Integrated Manufacturing, 16 (4-5), 283-291.

van der Vorst, J., \& Beulens, A. (2002). Identifying sources of uncertainty to generate supply chain redesign strategies. International Journal of Physical Distribution \& Logistics Management, 32 (6), 409-430.
VICS
(2004).
Collaborative

Transportation Management, CTM SubCommittee of the VICS Logistics Committee, available at: http://idii.com/wp/ctm.pdf, (last accessed August 2008).

Wang, C., \& Regan, A.C. (2003). Risks and Reduction Measures in Logistics Outsourcing, TRB Annual Meeting, CDROM, available at: http:/www.ltrc.lsu.edu/TRB_82/TRB2003001333.pdf (last accessed September, 2014).
Wilding, R., \& Juriado, R. (2004). Customer perceptions on logistics outsourcing in the European consumer goods industry. International Journal of Physical Distribution \& Logistics Management, 34 $(7 / 8), 628-644$. 